\title{
The Influence of Acesulfame-K and Aspartame on Some Physiological Parameters in Male Albino Rats
}

\author{
Eman G.E. Helal ${ }^{1}$, Mohamed A. Abdelaziz ${ }^{2}$, Neama M. Taha ${ }^{3}$ Mariam S. El-Gamal $^{1}$ \\ ${ }^{1}$ Department of Zoology, Faculty of Science (Girls), Al-Azhar University, ${ }^{2}$ Medical Physiology, \\ Faculty of Medicine, Al-Azhar University, ${ }^{3}$ Physiology Department, College of Medicine, \\ Umm Al-Qura University, KSA \\ *Corresponding author: Eman Helal, emanhelal@ hotmail.com, mobile 00201001025364, \\ orcid.org/0000-0003-0527-7028
}

\begin{abstract}
Background: the easiest method of reducing calories is to replace the high caloric food products with sweetened ones. Aim of the work: this study aimed to determine the effects of acesulfame-k or aspartame on some physiological parameters in male albino rats. Materials and methods: we used thirty male albino rats of local strain weighing from 100 to $120 \mathrm{gm}$. The period of the experiment was 30 days. The animals were divided into three groups; Group 1: control, Group 2: rats received acesulfame-k (15 mg/kg/day) and group 3: rats received aspartame $(50 \mathrm{mg} / \mathrm{kg} /$ day). Results: there was an increase in serum glucose and insulin level in rats that received aspartame. In addition, there was increase in ASAT and ALAT activities, serum creatinine, serum urea and lipid profile except HDL-C in both treated groups as compared to the control group. Meanwhile, there was a drop in serum testosterone level and serum T3\&T4 levels in aspartame group as well as in total protein, albumin and albumin/globulin ratio in both treated groups as compared to control group. Conclusion: aspartame has more dangerous effects than acesulfame-k.
\end{abstract}

Keywords: acesulfame-k, aspartame, ASAT, ALAT, T3, T4, testosterone, insulin.

\section{INTRODUCTION}

Most people prefer to eat sweet-tasting foods. Preloading experiences show that sweet taste, whether delivered with sugar or artificial sweeteners, enhances human appetite. Because of the concern that eating high sugars can increase the risk of obesity, diabetes, and cardiovascular disease, non-food sweeteners (NNSs) are increasingly being used to replace sugars. NNSs are marketed as dieting tools, and consumers can intuitively select NNS on sugar to maintain or lose weight. Most drinks, chewing gum, chocolates, jams and various NNS power authorities are used. There is emerging evidence indicating that NNSs have unanticipated effects on human health ${ }^{(\mathbf{1})}$.

Acesulfame potassium (also known as acesulfame $\mathrm{K}$, or K-Ice) is an industrial plant, sometimes referred to in Europe as the E950. It is a high density, non-nutritive analyzer 200 times better than sucrose. It is stable under high temperatures and has an excellent default life. Potassium acesulfame is used to give food and drink a taste that is soluble without adding calories. It is used as a sweetener in many foods, including chewing gum, baked foods, canned foods and desserts. Acesulfame potassium is not metabolized or stored in the body. It is quickly absorbed and then excreted without undergoing modifications. Acesulfame potassium contains the chemical methylene chloride, a known carcinogen. Long-term exposure to methylene chloride can cause headaches, depression, nausea, mental confusion, liver and kidney effects and cancer in humans ${ }^{(2)}$.
Another one of the byproducts of acesulfame potassium's

breakdown in the body is acetoacetamide, which is toxic at high doses. Centre for Science in the Public Interest (CSPI) noted that acetoacetamide has been shown to cause tumor growth in the thyroid gland in rats, rabbits, and dogs after administration of only $1 \%$ acetoacetamide in the diet for three months ${ }^{(3)}$.

Aspartame (ASP) is one of the most widely used artificial sweeteners. It consists of substances normally found in the diet and body, i.e. amino acids aspartic acid, phenylalanine and methane alcohol. After oral administration to human and experimental animals, ASP is metabolized quickly and fully into its three components. Consumption of ASP has been reported to be responsible for neurological and behavioral disturbances in sensitive individuals. The adverse neurological effects such as headaches, insomnia and seizures may be attributed to the alterations in regional brain concentrations of catecholamines ${ }^{(4)}$. In addition, Humphries et al. ${ }^{(5)}$ proposed that excessive aspartame ingestion might be involved in the pathogenesis of certain mental disorders and also in compromised learning and emotional functioning. Small amounts of ASP can significantly increase methanol $(\mathrm{MeOh})$ concentration in the bloodstream. $\mathrm{MeOH}$ has a relatively low toxicity, but its metabolites are very toxic. It is increasingly recognized as a substance that damages the liver cells, where it is oxidized to formaldehyde 
which is a factor that cause significant increase in lipid peroxidation ${ }^{(6)}$.

\section{MATERIALS AND METHODS}

Acesulfame-K was obtained as STEVIANA $^{\circledR}$, Manufactured in Jeddah- Saudi Arabia by Sald Salim Bawazir for Toothpaste and Sweetener Factory.

Aspartame was obtained as HERMESETAS, Made in Switzerland by Hermes Sweeteners Ltd, Zurich.

Thirty male albino rats (weighing from 100 to $120 \mathrm{~g}$ ) were used in this study. Animals were housed in stainless steel cages, fed on rat chow and offered water ad libidum. The animals were divided into three equal groups (10 rats each) as follows: The first group: the control untreated group, the second group: rats received orally acesulfame- $\mathrm{k}(15 \mathrm{mg} / \mathrm{kg}$ b.w. /day) and the third group: rats received orally aspartame $(50 \mathrm{mg} / \mathrm{kg}$ b.w. /day). Body weights were recorded at the beginning and the end of the experiment. After 30 days, animals were weighed and then decapitated.

Blood samples were collected for biochemical parameters. Blood samples were centrifuged for 15 min. at $5000 \mathrm{rpm}$ and supernatant sera were separated for analysis.

\section{Biochemical Examination}

In the present study, total protein (TP) and albumin concentrations were estimated. Then, serum globulin concentrations were calculated according to the formula:

\section{Globulin $(\mathrm{g} / \mathrm{dl})=$ total protein $(\mathrm{g} / \mathrm{dl})-$ albumin (g/dl)}

Aspartate aminotransferase (ASAT), alanine aminotransferase (ALAT) activities, creatinine, urea, glucose concentrations as well as lipid profile that including total cholesterol, triglycerides and highdensity lipoprotein cholesterol (HDL-C) were also determined. All parameters were estimated using BioMerieux SA kits, France.

The ratio of serum albumin/ globulin was determined. However, ratios of TC/HDL (risk factor 1) and LDL/HDL (risk factor 2) were also calculated after calculation of serum LDL-C (low-density lipoprotein cholesterol) and VLDL (very low-density lipoprotein cholesterol) using the Friedewald's ${ }^{(7)}$ and Norbert ${ }^{(8)}$ formulas, respectively as following:

Friedewald's ${ }^{(7)}$ equation: LDL $(\mathrm{mg} / \mathrm{dl})=$ TC$\{$ HDL + [TG/5] $\}$.

Norbert ${ }^{(8)}$ equation: VLDL $=$ TG/5

Insulin was determined by using ELISA kit (101250-01, Mercodia AB, Uppsala, Sweden). The HOMA-2 IR index (Homeostatic Model Assessment of Insulin Resistance) was calculated by a free online calculator (HOMA Calculator, Version
2.2.3, Diabetes Trail Unit, The University of Oxford, Oxford, UK).

HOMA-IR $=\frac{[(\text { Glycaemia }(\mathrm{mg} / \mathrm{dl}) / 18.2) \times \operatorname{Insulin}(\mathrm{mU} / \mathrm{ml})]}{22.517}$ (9)

Testosterone, T3 and T4 were estimated by using VIDAS $^{\circledR}$ kits, which are automated quantitative tests. Statistical analysis

The results were expressed as Mean \pm SEM of the mean. Data were analyzed by using T-test and were performed using the Statistical Package (SPSS) program, version 20. The Bonferroni test was used as a method to compare significance between groups.

\section{RESULTS}

As regards Body weight, no significant change was noticed in the percentage of body weight change in acesulfame-k group, while there was significant increase $(\mathrm{p}<0.05)$ in aspartame group as compared to control animals (Table 1 ).

In regard to Glucose level, there was no significant change in glucose level in acesulfame-k group, but there was highly significant increase $(\mathrm{p}<0.01)$ in aspartame group in contrast to control rats (Table 1).

Concerning Insulin level, the present study showed that there was no significant change in insulin level of acesulfame-k group, while there was highly significant increase $(p<0.01)$ in aspartame group as compared to control (Table 1).

Regarding HOMA-IR, there was no significant change observed in the ratio of HOMA-IR in acesulfame-k group, but there was highly significant increase $(p<0.01)$ in aspartame group in comparison with normal rats (Table 1).

Table (1): Percentage of body weight change, glucose level and HOMA-IR in control, acesulfame-k and aspartame treated animals.

\begin{tabular}{|c|c|c|c|}
\hline $\begin{array}{l}\text { Groups } \\
\text { Parameters }\end{array}$ & Control & \begin{tabular}{|c} 
Acesulfame- \\
$\mathbf{k}$
\end{tabular} & Aspartame \\
\hline $\begin{array}{l}\% \text { of body weight } \\
\text { change }\end{array}$ & $\begin{array}{c}8.6 \pm \\
0.5\end{array}$ & $9.5 \pm 0.4$ & $12 \pm 0.9 *$ \\
\hline $\begin{array}{l}\% \text { of change from } \\
\text { control }\end{array}$ & & $10 \%$ & $40 \%$ \\
\hline Glucose (mg/dl) & $\begin{array}{c}109 \pm \\
0.7\end{array}$ & $112 \pm 1.3$ & $\begin{array}{l}120 \pm \\
0.6 * *\end{array}$ \\
\hline $\begin{array}{l}\% \text { of change from } \\
\text { control }\end{array}$ & & $3 \%$ & $10 \%$ \\
\hline Insulin $(\mathrm{mlU} / \mathrm{ml})$ & $\begin{array}{l}0.97 \pm \\
0.007\end{array}$ & $0.99 \pm 0.008$ & $\begin{array}{c}1.8 \pm \\
0.041 * *\end{array}$ \\
\hline $\begin{array}{l}\% \text { of change from } \\
\text { control }\end{array}$ & & $2 \%$ & $86 \%$ \\
\hline HOMA-IR & $\begin{array}{l}0.26 \pm \\
0.003\end{array}$ & $0.27 \pm 0.005$ & $\begin{array}{c}0.53 \pm \\
0.008 * *\end{array}$ \\
\hline $\begin{array}{l}\% \text { of change from } \\
\text { control }\end{array}$ & & $4 \%$ & $103 \%$ \\
\hline
\end{tabular}

Values represent mean \pm SE (standard error).

$\left(P^{*}<0.05, P^{* *}<0.01\right.$ as compared to control group) 
As regards protein profile, animals that received acesulfame-k had significant decrease $(p<0.05)$ in serum total protein, albumin and albumin/globulin ratio, and those received aspartame showed highly significant decrease $(\mathrm{p}<0.01)$ in the previous parameters as compared to the corresponding control group (Table 2).

Table (2): Serum total protein, albumin, globulin and albumin/globulin ratio in control, acesulfame-k and aspartame-treated animals.

\begin{tabular}{|c|c|c|c|}
\hline $\begin{array}{c}\text { Groups } \\
\text { parameters }\end{array}$ & Control & $\begin{array}{c}\text { Acesulfame } \\
-k\end{array}$ & Aspartame \\
\hline $\begin{array}{l}\text { Total Protein } \\
(\mathrm{g} / \mathrm{dl})\end{array}$ & $\begin{array}{c}6.63 \pm \\
0.04\end{array}$ & $5.8 \pm 0.3^{*}$ & $3.9 \pm 0.1 * *$ \\
\hline $\begin{array}{l}\% \text { of change from } \\
\text { control }\end{array}$ & & $-13 \%$ & $-41 \%$ \\
\hline Albumin $(\mathrm{g} / \mathrm{dl})$ & $\begin{array}{l}3.43 \pm \\
0.046\end{array}$ & $2.7 \pm 0.23^{*}$ & $1 \pm 0.15^{* *}$ \\
\hline $\begin{array}{l}\% \text { of change from } \\
\text { control }\end{array}$ & & $-21 \%$ & $-71 \%$ \\
\hline Globulin $(\mathrm{g} / \mathrm{dl})$ & $\begin{array}{l}3.2 \pm \\
0.028\end{array}$ & $3.1 \pm 0.06$ & $2.9 \pm 0.14$ \\
\hline $\begin{array}{l}\% \text { of change from } \\
\text { control }\end{array}$ & & $-3 \%$ & $-10 \%$ \\
\hline Albumin/Globulin & $\begin{array}{c}1.074 \pm \\
0.02\end{array}$ & $0.87 \pm 0.07 *$ & $\begin{array}{c}0.3 \pm \\
0.06^{* *}\end{array}$ \\
\hline $\begin{array}{l}\% \text { of change from } \\
\text { control }\end{array}$ & & $-19 \%$ & -72 \\
\hline
\end{tabular}

Values represent mean $\pm \mathrm{SE}$ (standard error). $\left(P^{*}<0.05\right.$, $P^{* *}<0.01$ as compared to control group)

In regard to liver functions, ASAT and ALAT activities revealed significant increase $(\mathrm{p}<0.05)$ among acesulfame-k group and highly significant increase $(\mathrm{p}<0.01)$ among aspartame group in contrast with control rats (Table 3 ).

Table (3): ASAT and ALAT activities in control, acesulfame-k and aspartame treated animals.

\begin{tabular}{|c|c|c|c|}
\hline $\begin{array}{r}\text { Groups } \\
\text { parameters }\end{array}$ & Control & $\begin{array}{c}\text { Acesulfame } \\
-\mathbf{k}\end{array}$ & Aspartame \\
\hline ASAT (U/L) & $115.88 \pm 0.3$ & $120 \pm 1.2^{*}$ & $183 \pm 0.9^{* *}$ \\
\hline \begin{tabular}{l}
\multicolumn{1}{c}{$\%$ of } \\
change from \\
control
\end{tabular} & & $4 \%$ & $58 \%$ \\
\hline ALAT (U/L) & $55.4 \pm 0.16$ & $60 \pm 1.4^{*}$ & $85 \pm 1.1 * *$ \\
\hline $\begin{array}{l}\text { \% of change } \\
\text { om control }\end{array}$ & & $8 \%$ & $53 \%$ \\
\hline
\end{tabular}

Regarding lipid profile, the present results revealed significant increase $(p<0.05)$ in total cholesterol, triglycerides and LDL-C, significant decrease $(\mathrm{p}<$ 0.05 ) in HDL-C, and no significant change in VLDL$\mathrm{C}$ and ratios of TC/HDL-C (risk factor 1 ) and LDL$\mathrm{C} / \mathrm{HDL}-\mathrm{C}$ (risk factor 2) in rats received acesulfame- $\mathrm{k}$ as compared to control group. Meanwhile, there was highly significant increase $(p<0.01)$ in total cholesterol, triglycerides and LDL-C, significant decrease $(\mathrm{p}<0.05)$ in HDL-C, no detectable change in VLDL-C and significant increase $(p<0.05)$ in risk factors in rats received aspartame as compared to control group (Table 4).

Table (4): Changes in total cholesterol (TC), triglyceride (TG), HDL-C, LDL-C, VLDL-C, TC/HDL ratio and LDL/HDL ratio in control, acesulfame-k and aspartame treated animals.

\begin{tabular}{|c|c|c|c|}
\hline $\begin{array}{c}\text { Groups } \\
\text { parameters }\end{array}$ & Control & $\begin{array}{c}\text { Acesulfame } \\
-\mathbf{k}\end{array}$ & Aspartame \\
\hline $\begin{array}{l}\text { Total Cholesterol } \\
(\mathrm{mg} / \mathrm{dl})\end{array}$ & $\begin{array}{c}121.1 \pm \\
0.38\end{array}$ & $127 \pm 1.7 *$ & $140 \pm 1.2 * *$ \\
\hline $\begin{array}{l}\% \text { of change } \\
\text { from control }\end{array}$ & & $5 \%$ & $16 \%$ \\
\hline $\begin{array}{l}\text { Triglycerides } \\
(\mathrm{mg} / \mathrm{dl})\end{array}$ & $135 \pm 0.7$ & $140 \pm 1.4^{*}$ & $150 \pm 0.9 * *$ \\
\hline $\begin{array}{l}\% \text { of change } \\
\text { from control }\end{array}$ & & $4 \%$ & $11 \%$ \\
\hline HDL-C (mg/dl) & $59.4 \pm 0.48$ & $55 \pm 1.2 *$ & $45 \pm 0.7 * *$ \\
\hline $\begin{array}{l}\% \text { of change } \\
\text { from control }\end{array}$ & & $-7 \%$ & $-24 \%$ \\
\hline LDL-C (mg/dl) & $34.6 \pm 0.48$ & $44 \pm 2.7 *$ & $65 \pm 2.1 * *$ \\
\hline $\begin{array}{l}\% \text { of change } \\
\text { from control }\end{array}$ & & $27 \%$ & $88 \%$ \\
\hline VLDL (mg/dl) & $27 \pm 0.1$ & $28 \pm 0.8$ & $30 \pm 1.4$ \\
\hline $\begin{array}{l}\% \text { of change } \\
\text { from control }\end{array}$ & & $4 \%$ & $11 \%$ \\
\hline TC/HDL & $\begin{array}{l}2.04 \pm \\
0.015 \\
\end{array}$ & $2.3 \pm 0.18$ & $3.1 \pm 0.31 *$ \\
\hline $\begin{array}{l}\% \text { of change } \\
\text { from control }\end{array}$ & & $13 \%$ & $52 \%$ \\
\hline LDL/HDL & $0.6 \pm 0.01$ & $0.8 \pm 0.13$ & $1.4 \pm 0.25^{*}$ \\
\hline $\begin{array}{l}\% \text { of change } \\
\text { from control }\end{array}$ & & $33 \%$ & $133 \%$ \\
\hline
\end{tabular}

Concerning kidney functions, serum urea and creatinine showed significant increase $(p<0.05)$ in acesulfame-k group and highly significant increase ( $\mathrm{p}$ $<0.01)$ in aspartame group as compared to control animals (Table 5).

Table (5): Serum urea and creatinine levels in control, acesulfame-k and aspartame treated animals.

\begin{tabular}{|l|c|c|c|}
\hline Groups & Control & $\begin{array}{c}\text { Acesulfame } \\
\text { parameters }\end{array}$ & Aspartame \\
\hline Urea (mg/dl) & $\begin{array}{c}37.3 \pm \\
0.66\end{array}$ & $42 \pm 1.3^{*}$ & $55 \pm 0.8^{* *}$ \\
\hline $\begin{array}{l}\text { \% of change } \\
\text { from control }\end{array}$ & & $13 \%$ & $47 \%$ \\
\hline $\begin{array}{l}\text { Creatinine } \\
\text { (mg/dl) }\end{array}$ & $1.18 \pm$ & $1.6 \pm 0.13^{*}$ & $2.3 \pm$ \\
\hline$\%$ of change & 0.025 & & $0.09^{* *}$ \\
from control & & $36 \%$ & $95 \%$ \\
\hline
\end{tabular}


Values represent mean \pm SE (standard error).

$\left(P^{*}<0.05, P^{* *}<0.01\right.$ as compared to control group)

In relation to hormones, acesulfame-k group revealed no detectable change in the level of testosterone hormone, but there was a highly significant decrease $(\mathrm{p}<0.01)$ found in its level in aspartame group as compared to control rats. On the other hand, no detectable change was noticed in the levels of both T3 and T4 concentrations in acesulfame-k group, but aspartame group showed significant decrease $(\mathrm{p}<0.05)$ in their concentrations as compared to control values (Table 6).

Table (6): Serum testosterone, T3 and T4 levels in control, acesulfame-k and aspartame treated animals.

\begin{tabular}{|l|c|c|c|}
\hline $\begin{array}{l}\text { Groups } \\
\text { parameters }\end{array}$ & Control & $\begin{array}{c}\text { Acesulfame } \\
-\mathbf{k}\end{array}$ & Aspartame \\
\hline $\begin{array}{l}\text { Testosterone } \\
\text { (ng/dl) }\end{array}$ & $\begin{array}{c}1.03 \pm 0 . \\
004\end{array}$ & $0.95 \pm 0.04$ & $\begin{array}{c}0.55 \pm \\
0.05^{* *}\end{array}$ \\
\hline $\begin{array}{l}\% \text { of change } \\
\text { from control }\end{array}$ & & $-8 \%$ & $-47 \%$ \\
\hline T3 (ng/dl) & $\begin{array}{c}47.9 \pm 0 . \\
6\end{array}$ & $46 \pm 1.3$ & $42 \pm 1.69^{*}$ \\
\hline $\begin{array}{l}\% \text { of change } \\
\text { from control }\end{array}$ & & $-4 \%$ & $-12 \%$ \\
\hline $\begin{array}{l}\text { T4 }(\mu \mathrm{g} / \mathrm{dl}) \\
\% \text { of change } \\
\text { from control }\end{array}$ & $\begin{array}{c}.036 \pm 0 \\
\text { Valu }\end{array}$ & $2.8 \pm 0.12$ & $2 \pm 0.31^{*}$ \\
\hline
\end{tabular}

Values represent mean $\pm \mathrm{SE}$ (standard error).

$\left(P^{*}<0.05, P^{* *}<0.01\right.$ as compared to control group)

\section{DISCUSSION}

In this study, we demonstrated that a lowcalorie solution of aspartame administered to rats increased body weight compared to control group. Aspartame increases appetite through metabolites by different mechanisms. As a precursor of catecholamine neurotransmitters, phenylalanine may facilitate food intake via the hypothalamic adrenoreceptors, implicated in the central appetite control mechanisms and thus stimulating appetite ${ }^{(\mathbf{1 0})}$. The aspartame metabolite aspartate is taken over from circulation by the arcuate (ARC) nucleus in the brain. The ARC nucleus is the main place for the synthesis of neuropeptide Y (NPY), which stimulates carbohydrate intake ${ }^{(\mathbf{1 1})}$. Aspartate is an N-Methyl-Daspartate (NMDA) receptors agonist and its increased concentration can influence food intake (12). Aspartame use significantly decreases the concentrations of leptin in plasma. Leptin acts on the brain by inhibiting food intake, but lower concentrations of leptin could stimulate appetite ${ }^{(\mathbf{1 3})}$. Feijo et al. ${ }^{(14)}$ also reported that there was an increase in body weight and fluid intake in a group of rats treated with aspartame.
There was a very significant increase in the glucose level in rats received aspartame compared to the control group. High blood glucose levels in the aspartame group can be attributed to the formation of amino acids from aspartame, where phenylalanine is considered to be both glucokinetic and ketone, while aspartic acid is a partial amino acid gluogin and thus converted to glucose. The glycogenolytic effect of aspartame may be due to its direct effect on cell stimulating glycogenolysis or due to its effect on other cytoplasmic membranous organelles and the associated enzymes necessary for glycogen synthesis (15)

In our study, only aspartame increased insulin level significantly. This may be due to phenylalanine (which is a component of aspartame). This amino acid is nutrient-signaling molecule, which stimulates arise of insulin and glucagon concentration and has a regulatory effect on the metabolism of glucose ${ }^{(16)}$. People at risk of diabetes type 2 are advised to avoid consuming aspartame to prevent the potential beta cell defects caused by hyperinsulinemia (17)

Aspartame increased glucose, insulin and HOMA-IR and this is an evidence that aspartame can cause type 2 diabetes.

In the present work, there was an obvious decrease in protein profile in both acesulfame-k and aspartame treated groups as compared to control rats. Yousef et $\boldsymbol{a l} .{ }^{(18)}$ referred to the inhibitory effect of some food additives on the biosynthesis of protein and albumin which in turn reflects impairment in liver functions. Furthermore, reductions of protein profile in the treated groups indicates hepatotoxicity and liver damage that led to inability of liver to produce proteins and causing utilization of amino acids for the oxidation or gluconeogenesis ${ }^{(19)}$.

We observed a significant increase in ALAT and ASAT activities in acesulfame-k-treated rats and highly significant increase of these activities in aspartame-treated rats. The increased levels of serum liver enzymes in both groups indicate an enhanced permeability, damage or necrosis of hepatocytes. The disturbance in the transport function of the hepatocytes resulted from hepatic injury. The alterations in enzyme levels in liver may depend on exposure time and dose ${ }^{(6)}$.

Our study clearly indicated that TC, TG and LDL-cholesterol were significantly increased, whereas HDL-cholesterol level was significantly decreased on rats received acesulfame-k or aspartame when compared to control. The long-term consumption of artificial sweeteners might induce atherosclerosis via modifying Apo A-1 and cause protein cleavage, which is associated with loss of antioxidant ability and impairment of phospholipid- 
binding ability ${ }^{(20)}$. Apo A1 structure modification could lead to the production of dysfunctional HDLcholesterol (21). In addition, chronic exposure to aspartame induced changes in lipid metabolism and could be involved in the development of hypercholesterolemia ( ${ }^{(6)}$ and atherosclerosis (20). Hypercholesterolemic atherosclerosis was associated with increased ROS, which represent a critical initiating event in the development of atherosclerosis and cardiovascular disease (22). Superoxide anion facilitates oxidative modification of LDL-cholesterol that plays a key role in the formation of atherosclerotic lesions ${ }^{(23)}$.

There was a significant increase in serum urea and creatinine concentrations in rats received acesulfame-k but there was highly significant increase in their concentrations in rats received aspartame. The increase of these biomarkers levels indicates an enhanced permeability, tissue damage or necrosis due to formation of free radicals in all tissues from glucose auto-oxidation and protein glycosylation ${ }^{(24)}$. Also, the elevation of serum urea and creatinine in aspartame-treated rats could be due to a sudden decrease in glomerular filtration rate by the majority of methanol (which is a component of aspartame) that enters proximal tubular epithelial cells binds to anionic phospholipids inducing abnormalities in function and metabolism of multiple intracellular membranes and organelles in these cells (25)

In the present work, there was highly significant decrease in testosterone concentration in rats received aspartame as compared to control group. Aspartame works to reduce androgens which indirectly affect the axis connecting the pituitary gland. This has negative effects on social behavior and the relative weight of members of the sexproducing hormone (26). Deficiencies of the testosterone hormone might cause social behavioral changes because of its importance in the regulation of aggression in mammals ${ }^{(27)}$. Exposure to aspartame negatively affects the concentration of neurotransmitters. This suggests that it causes changes in social behavior, increases isolation and lack of social movements ${ }^{(28)}$.

Also, in LT Men's clinic ${ }^{(29)}$ they revealed that:" aspartame may cause low testosterone". Aspartame is called excitotoxin. It has the ability to bind to different brain receptors, causing them to take in too many calcium ions and eventually causing damage. Unfortunately, these negative effects can not only impact the brain but testosterone production as well ${ }^{(29)}$.

Our study demonstrated that there was a significant decrease in T3 and T4 hormones of rats received aspartame. Aspartame is composed of two amino acids, phenylalanine and aspartame, which are connected to methanol ${ }^{(30)}$. Aspartame in the body further metabolizes to formaldehyde ${ }^{(31)}$. Moreover, a study done on male albino rats showed that formaldehyde (a metabolite of aspartame) causes the regression of the follicular epithelial cells of the thyroid gland, which leads to decreased levels of T3 and T4, and increased TSH levels. There is a possibility that, initially, formaldehyde increases the stimulation of the thyroid follicles, which rapidly worsens the synthetic capacity of the gland. This ultimately leads to the failure of the thyroid gland ${ }^{(32)}$. Formaldehyde, a metabolite of aspartame is reported to be associated with type IV delayed hypersensitivity (33)

According to a report presented at 2015, International Thyroid Congress ${ }^{(34)}$ reported that the use of aspartame may be linked to the development of a type of hypothyroidism called Hashimoto's thyroid disease (HT). Aspartame elevated levels of thyroid stimulating hormone (TSH). Increased TSH levels are considered indicative of hypothyroidism ${ }^{(35)}$.

Conclusion: in summary, aspartame must be banned from using by consumers due to its deleterious effects on almost physiological parameters. Acesulfame potassium has lower effects than aspartame, but in general, it is better to replace both of them with natural sweeteners to be away from any health problems that may be caused by them.

\section{REFERENCES}

1. Wang Q-P, Browman D, Herzog H et al. (2018): Non-nutritive sweeteners possess a bacteriostatic effect and alter gut microbiota in mice. PLoS ONE, 13 (7): e0199080.

2. ATSDR (1998): Agency for Toxic Substances and Disease Registry. Toxicological Profile for Methylene Chloride (Update). Draft for Public Comment. Public Health Service, U.S. Department of Health and Human Services, Atlanta, GA.

3. Findikli Z, Turkoglu S (2014): Determination of the effects of some artificial sweeteners on human peripheral lymphocytes using the comet assay. Journal of Toxicology and Environmental Health Sciences, 6 (8): 147-153.

4. Mourad IM, Noor NA (2011): Aspartame (a widely used artificial sweetener) and oxidative stress in the rat cerebral cortex. Int J Pharm Biomed Sci., 2 (1): 4-10.

5. Humphries $\mathbf{P}$, Pretorius E, Naudé H (2008): Direct and indirect cellular effects of aspartame on the brain. Eur J Clin Nutr., 62: 451.

6. Prokić MD, Paunović MG, Matić MM et al. (2015): Effect of aspartame on biochemical and oxidative stress parameters in rat blood. Arch. Biol. Sci., 67 (2), 535-545.

7. Friedewald WT, Levy RI, Fredrickson DS et al. (1972): Estimation of the concentration of low-density lipoprotein cholesterol in plasma, without use of the preparative ultracentrifuge. Clin. Chem., 18: 499-502. 
8. Norbert WT (1995): Clinical guide to laboratory tests. 3rd ed. Saunders W. B., Company, Philadelphia.

9. Rosales-Gómez CA, Martínez-Carrillo BE, Reséndiz-Albor AA et al. (2018): Chronic Consumption of Sweeteners and Its Effect on Glycaemia, Cytokines, Hormones, and Lymphocytes of GALT in CD1 https://www.hindawi.com/journals/bmri/2018/134528 2/

10. Leibowitz SF (1980): Neurochemical systems of the hypothalamus- control of feeding and drinking behaviour and water electrolyte excretion. In: Handbook of the Hypothalamus. Eds. P.J. Morgane, and J. Panksepp, Marcel Dekker, New York, pp: 299343.

11. Bec B, Burlet A, Max JP et al. (2001): Effects of long-term ingestion of aspartame on hypothalamic neuropeptide $\mathrm{Y}$, plasma leptin and body weight gain and composition. Physiol. Behav., 75: 41-47.

12. Chen PE, Geballe MT, Stansfeld PJ et al. (2005): Structural features of the glutamate-binding site in recombinant NR1/NR2A N-methyl-D-aspartate receptors determined by site-directed mutagenesis and molecular modeling. Mol. Pharmacol., 67: 1470-1484.

13. Caro JF, Sinha MK, Kolaczynski JW et al. (1996): Leptin. The tale of an obesity gene. Diabetes, 45: 1455-1462.

14. Feijo FM, Ballard CR, Foletto KC et al. (2013): Saccharin and aspartame, compared with sucrose, induce greater weight gain in adult Wistar rats, at similar total caloric intake levels. Appetite, 60: 203207.

15. Abdallah IZA (2002): Physiological changes induced by long term administration of saccharin compared with aspartame to male albino rats. The Egyptian Journal of Hospital Medicine, 8: 70-81.

16. Nuttall FQ, Schweim KJ, Gannon MC (2016): Effect of orally administered phenylalanine with and without glucose on insulin, glucagon and glucose concentrations. Hormone and Metabolic Research, 38 (8): 518-23.

17. Imad J, Wehbe T, Jaoude EA (2017): A comparative study of three non nutritive sweeteners effects on insulin and glucose in healthy, non-diabetic adults. Insights Nutr Metabol., 1 (2): 73-79.

18. Yousef MI, Omar SA, El-Guendi MI et al. (2010): Potential protective effects of quercetin and curcumin on paracetamol-induced histological changes, oxidative stress, impaired liver and kidney functions and haematotoxicity in rat. Food Chem. Toxicol., 48: 3246-3261

19. Helal EGE, El-Sayed RAA, Mustafa MA et al. (2017): Adverse effects of two kinds of food additive mixtures (flavor enhancer, food preservative or food coloring agent) on physiological parameters in young male albino rats. The Egyptian Journal of Hospital Medicine, 67 (1): 344- 351.
20. Jang W, Jeoung NH, Cho K (2011): Modified apolipoprotein (apo) A-I by artificial sweetener causes severe premature cellular senescence and atherosclerosis with impairment of functional and structural properties of apoA-I in lipid-free and lipidbound state. Mol. Cells, 31: 461-470.

21. Feng H, Li X(2009): Dysfunctional high-density lipoprotein. Curr. Opin. Endocrinol. Diabetes. Obes., 16 (2): 156-162.

22. Chaitanya KV, Pathan AA, Mazumdar et al. (2010): Role of oxidative stress in human health: an overview. J.Pharmacy Research, 3 (6): 1330-1333.

23. Azeez $O$ and Alkass S (2018): effect of long-term consumption of aspartame on body weight, blood glucose, lipid profile, and kidney and liver fuction in rats. International Journal of Current Advanced Research, 7 (1): 14464-14474.

24. Chaitanya KV, Pathan AAK, Mazumdar SS et al. (2010): Role of oxidative stress in human health. An overview. . J Pharm Res., 3: 330-1333.

25. AbdElwahab AH, Yousuf AF, Ramadan BK et al. (2017): Comparative effects of stevia rebaudiana and aspartame on hepato-renal function of diabetic rats: biochemical and histological approaches. Journal of Applied Pharmaceutical Science, 7 (8): 34-42.

26. Sun Y, Hsu H, Lue S et al. (1991): Sex-Specific impairment in sexual and ingestive behaviors of monosodium glutamate-Treated rats. Physiol. Behav., 50: 873-880.

27. Terry LC, Epelbaum J, Martin JB (1981): Monosodium glutamate: acute and chronic effects on rhythmic growth hormone and prolactin secretion, and somatostatin in the undisturbed male rat. Brain Res., 217: 129-142.

28. Abu-Taweel GM (2016): effect of monosodium glutamate and aspartame on behavioral and biochemical parameters of male albino mice. African Journal of Biotechnology, 15 (15): 601-612.

29. https://Itmensclinic.com/can-aspartame-artificialsweetener-affect-testosterone-levels/

30. Yang Q (2010): Gain weight by "going diet?" Artificial sweeteners and the neurobiology of sugar cravings. Yale J Biol Med., 83: 101-108.

31. Trocho C, Pardo R, Rafecas I et al. (1998): Formaldehyde derived from dietary aspartame binds to tissue components in vivo. Life Sci., 63: 337-349.

32. Patel KG, Bhatt HV, Choudhury AR (2003): Alteration in thyroid after formaldehyde (HCHO) treatment in rats. Ind Health, 41: 295-297.

33. Sachmechi I, Khalid A, Awan S I et al. (2018): Autoimmune Thyroiditis with Hypothyroidism Induced by Sugar Substitutes. Cureus, 10 (9): e3268.

34. https://www.liebertpub.com/doi/full/10.1089/thy.20 15.29006.abstracts

35. https://www.verywellhealth.com/thyroid-patientsshould-avoid-artificial-sweeteners-3233020 